\title{
Celebrating 20 years of open access publishing at BMC Musculoskeletal Disorders
}

\author{
Ciarán Martin Fitzpatrick* and Amanpreet Athwal
}

\begin{abstract}
Twenty years ago, on October 23, the first article published by BMC Musculoskeletal Disorders appeared free online. Over 5700 publications later, we celebrate our anniversary as the largest Open Access journal in the 'Orthopaedics and Sports Medicine' and 'Rheumatology' fields. Our 'open, inclusive, and trusted' ethos, along with our efficient and robust peer review services, are recognized by the musculoskeletal field.

The early pioneers of BMC Musculoskeletal Disorders pushed the Open Access publishing model, in order to better support the needs of both the clinical and research communities. We pride ourselves on the continual innovation of author services, data transparency, and peer review models. These advances would not have been possible without your efforts - so a massive thank you to all the authors, editorial teams, and reviewers who have contributed to our success. Excellent reviewers are the nucleus of any thriving journal, and we have been lucky to collaborate with so many talents.
\end{abstract}

\section{Main text}

Twenty years ago, on October 23, the first article published by BMC Musculoskeletal Disorders appeared free online [1]. Over 5700 publications later, we celebrate our anniversary as the largest Open Access journal in the 'Orthopaedics and Sports Medicine' and 'Rheumatology' fields. Our 'open, inclusive, and trusted' ethos, along with our efficient and robust peer review services, are recognized by the musculoskeletal field.

The early pioneers of BMC Musculoskeletal Disorders pushed the Open Access publishing model, in order to better support the needs of both the clinical and research communities. We pride ourselves on the continual innovation of author services, data transparency, and peer review models. These advances would not have been possible without your efforts - so a massive thank you to all the authors, editorial teams, and reviewers who have contributed to our success. Excellent reviewers are the nucleus of any thriving journal, and we have been lucky to collaborate with so many talents.

We take this opportunity to look back on some highlights and milestones in our partnership with our diverse community:

- 2,350,000 article downloads in 2011; one metaanalysis on stabilisation exercises for back pain is our most clicked study ever with 123,000 reads [2].

- 13,332 citations in 2019; the disabilities of the arm, shoulder and hand (DASH) outcome questionnaire has been cited an impressive 581 times [3].

- Recent article collections on osteoarthritis, work and musculoskeletal health, and imaging provided a venue for deeper investigation into important topics.

* Correspondence: ciaran.fitzpatrick@springernature.com

BMC Series, Springer Nature, 4 Crinan Street, London N1 9XW, UK

C C The Author(s). 2020 Open Access This article is licensed under a Creative Commons Attribution 4.0 International License, which permits use, sharing, adaptation, distribution and reproduction in any medium or format, as long as you give appropriate credit to the original author(s) and the source, provide a link to the Creative Commons licence, and indicate if changes were made. The images or other third party material in this article are included in the article's Creative Commons licence, unless indicated otherwise in a credit line to the material. If material is not included in the article's Creative Commons licence and your intended use is not permitted by statutory regulation or exceeds the permitted use, you will need to obtain permission directly from the copyright holder. To view a copy of this licence, visit http://creativecommons.org/licenses/by/4.0/ The Creative Commons Public Domain Dedication waiver (http://creativecommons.org/publicdomain/zero/1.0/) applies to the data made available in this article, unless otherwise stated in a credit line to the data. 


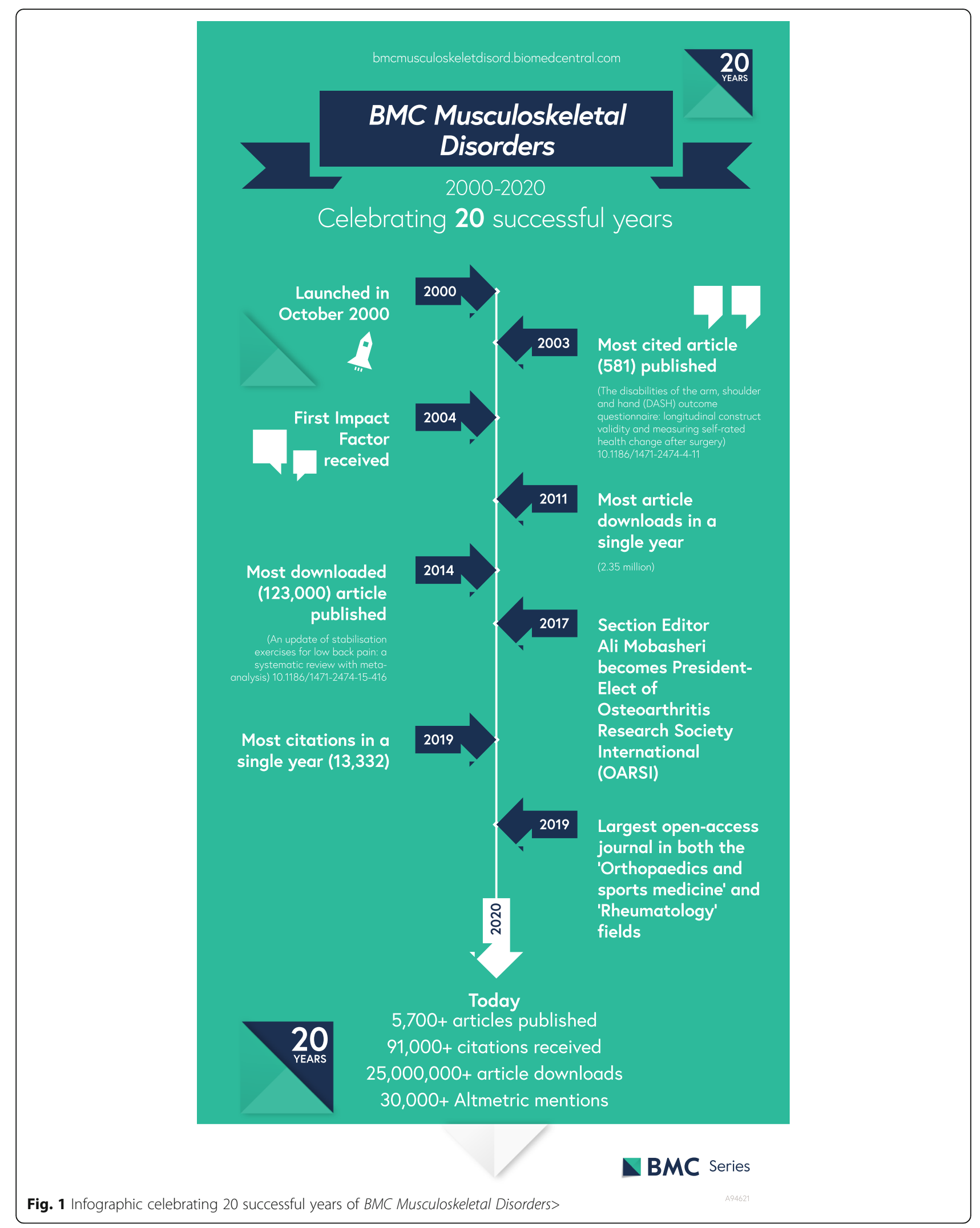


As part of the BMC Series policy, we do not make editorial decisions on the basis of the interest of a study or its likely impact. Studies must be scientifically valid, for research articles this includes; a scientifically sound research question, the use of suitable methods and analysis, and following community-agreed standards relevant to the research field. Our leadership in editorial policies has allowed thousands of authors to maximise the reach and readership of their work around the world, with 25,000,000+ article downloads and 91,000+ citations to date.

As the field acknowledges that $\mathrm{OA}$ is here to stay and continues to thrive, we highlight some future advances in the field that we excite us:

- Preprint publishing provides a service for the rapid dissemination of preliminary research findings. A preprint is a finalized draft of a research manuscript that is shared publicly online pre-peer review. $B M C$ Musculoskeletal Disorders, in partnership with Research Square, launched In Review to facilitate this option. Authors benefit by receiving credit, feedback, and visibility for their submitted work. Manuscripts can be tracked, allowing authors to view from when reviewers are invited to when reports are received. 500+ preprints have already been posted on our In Review site.

- Rapid progress in musculoskeletal imaging and digital health is reaching a tipping point, with these applications finally becoming commonly used in clinical practice. Artificial intelligence and data science fuel this transition to the mainstream, and BMC Musculoskeletal Disorders will highlight these topics.

- Empowered patient and public involvement in research is something that delights us $[4,5]$. The notion that research and clinical practice be geared towards the needs of patients, as well as involving them, is increasingly realized by funding and healthcare organisations. BMC Musculoskeletal Disorders is working to recognize and engage patients.

Scientific journals should benefit society, contributing to the patient and research communities we serve. This is BMC Musculoskeletal Disorders expectation for the next 20 years, as we take this moment to look into the horizon whilst celebrating with birthday cake.

\section{Supplementary Information}

The online version contains supplementary material available at https://doi. org/10.1186/s12891-020-03785-2.

Additional file 1. Supplementary Video. https://www.youtube.com/ watch?v=0gq36uhr2jg.
Acknowledgements

The authors would like to wholeheartedly thank all our authors, editorial teams, and reviewers.

Authors' contributions

All authors engaged in the writing, revising, and approving this piece. All authors read and approved the final manuscript.

Funding

Not applicable.

Availability of data and materials

Not applicable.

Ethics approval and consent to participate

Not applicable.

Consent for publication

Not applicable.

Competing interests

Both authors are employees of BMC and work in the BMC Musculoskeletal Disorders Editorial Office.

Published online: 21 November 2020

References

1. Gruber HE, Handey EN Jr. Human disc cells in monolayer vs 3D culture: cell shape, division and matrix formation. BMC Musculoskelet Disord. 2000;1:1.

2. Smith BE, Littlewood C, May S. An update of stabilisation exercises for low back pain: a systematic review with meta-analysis. BMC Musculoskelet Disord. 2014;15:416.

3. Gummesson C, Atroshi I, Ekdahl C. The disabilities of the arm, shoulder and hand (DASH) outcome questionnaire: longitudinal construct validity and measuring self-rated health change after surgery. BMC Musculoskelet Disord. 2003;4:11.

4. Vitaloni M, Botto-van Bemden A, Sciortino Contreras RM, Scotton D, Bibas M, Quintero M, Monfort J, Carné X, de Abajo F, Oswald E, Cabot MR, Matucci M, du Souich P, Möller I, Eakin G, Verges J. Global management of patients with knee osteoarthritis begins with quality of life assessment: a systematic review. BMC Musculoskelet Disord. 2019;20:493.

5. Bech B, Lykkegaard JJ, Lundbak T, Schrøder HM, Birkeland LM, Lund Schlyter ML, Hansen LH, Dalsgaard L, Appel EB. Patient-initiated follow-up (PIFU) as reorganized support for increased patient involvement - focus group discussions among patients' with inflammatory arthritis. BMC Rheumatology. 2020;4:44.

\section{Publisher's Note}

Springer Nature remains neutral with regard to jurisdictional claims in published maps and institutional affiliations.
Ready to submit your research? Choose BMC and benefit from:
- fast, convenient online submission
- thorough peer review by experienced researchers in your field
- rapid publication on acceptance
- support for research data, including large and complex data types
- gold Open Access which fosters wider collaboration and increased citations
- maximum visibility for your research: over $100 \mathrm{M}$ website views per year
At BMC, research is always in progress.
Learn more biomedcentral.com/submissions 